\title{
ANALISIS PROSPEK BANK SYARIAH DAN LEMBAGA KEUANGAN ISLAM DALAM MEMASUKI PASAR NEGARA INGGRIS
}

Iwan Fahri Cahyadi

${ }^{1}$ Institut Agama Islam Negeri Kudus, Kudus

$\bowtie$ iwanfahri@stainkudus.ac.id

Abstract $\quad:$ Globalization is a great business opportunity for the company Multi National Corporation (MNC) and Trans National Corporation (TNC) for expanding his business. Change the direction of economic policy, in particular the Shariahbased business that provides an opportunity for Islamic banking and Islamic financial institutions to expand his business in continental Europe, especially in the United Kingdom.

The purpose of the research was to find out, the strategy of Islamic banks and Islamic financial institutions to enter the market in the United Kingdom and prospeknya countries in the foreseeable future. The research method used is qualitative diskriptif fenomenalogi approach i.e. we allow qualitative researchers implement and apply subjective abilities and exploratory process in interpersonalnya. As for the source of the data retrieved from the data of the secondary data source i.e. who do not directly provide data to a data gatherer, e.g. documents, journals, research, books, and Government regulations.

The results showed that the market in the countries of United Kingdom Islamic business very promising in the future given the growth of the Muslim population from year to year are experiencing significant increase and economic growth in the United Kingdom

Keywords $\quad$ : Islamic Banking, Globalization, Muslim in the United Kingdom

\section{LATAR BELAKANG}

Globalisasi kegiatan ekonomi dan persoalan pengelolaannya sering dianggap orang baru muncul setelah Perang Dunia II., khususnya pada tahun 1960-an. Masa sesudah tahun 1960-an adalah masa munculnya perusahaan multinasional. Kemudian, setelah sistem nilai tukar setengah-tetap Bretton Woods ditinggalkan pada tahun 1971-1973, investasi dalam bentuk surat-surat berharga international dan pemberian kredit oleh bank mulai berkembang dengan cepat, seiring dengan meluasnya pasar modal ke seluruh dunia, yang menambah rumit hubungan ekonomi internasional dan membuka jalan bagi globalisasi ekonomi dunia yang terintegrasi dan saling tergantung.

Sejarah meluasnya kegiatan perusahaan ke seluruh dunia adalah sejarah teramat panjang, dan bukannya baru dimulai pada tahun 1960. Kegiatan dagang, misalnya, telah ada sejak zaman peradaban kuno, tetapi pada Abad Pertengahan, barulah di Eropa, muncul kegiatan dagang yang teratur lintas negara, yang dilakukan oleh lembaga-lembaga yang sifatnya korporasi swasta (meski seringkali mendapat dukungan dan bantuan yang besar dari pemerintahnya.

Pada abad ke-14, misalnya, Hanseatic League, sebuah himpunan pedagangpedagang Jerman, menjalankan kegiatan usaha di Eropa Barat dan di daerah Levant- 
mereka bergerak dibidang pertanian, penempaan besi dan produksi barang pada umumnya. Kira-kira pada masa itu pula para pedagang petualang memperdagangkan wol dan tekstil yang dihasilkan Inggris ke Belanda, Belgia, Luxemburg, dan negaranegara lain. Selain itu, di Italia, perusahaan-perusahaan dagang dan bank-bank memainkan peranan penting dalam kegiatan perdagangan ke seluruh dunia pada masa-masa awal Renaissance. Pada abad ke-14, di Italia, ada sekitar 150 bank yang sudah melakukan kegiatan di berbagai negara.

Dalam abad ke-17 dan ke-18 dukungan oleh negara meluas dengan berdirinya perusahaan-perusahaan besar kolonial, seperti Dutch East India Company, British East India Company, Muscovy Company, Royal Africa Company dan Hudson Bay Company. Semua perusahaan ini mempelopori perdagangan berskala besar di wilayah yang kelak menjadi wilayah jajahan yang penting.

Tetapi, penyebaran industri ke seluruh dunialah, sebagai akibat dari revolusi industri, yang paling dekat dengan perusahaan multinasional di zaman modern. Di sini peranan perusahaan Inggris sebagai perusahaan multinasional pertama penghasil barang pabrik tampak jelas. Mula-mula Amerika Utara dan Amerika Selatan membuka peluang untuk penanaman modal yang saling menguntungkan, disusul kemudian oleh Afrika dan Australasia. Muncul perdebatan apakah "investasi kolonial" dapat dianggap pendahulu penanaman modal asing, tetapi yang pasti produksi untuk pasar lokal mulai dengan cara ini. Perkembangan teknik dan industri setelah tahun 1870-an memungkinkan berbagai jenis barang yang sama dapat dihasilkan di dalam dan di luar negeri oleh perusahaan yang sama, sementara eksplorasi dan pengelolaan barang tambang dan bahan baku lainnya juga menarik penanaman modal asing dalam jumlah besar.

Namun, salah satu masalah dengan klasifikasi yang berlaku surut seperti itu adalah konsep modern " penanaman modal asing" di satu pihak (ada pengendalian dari luar) dan investasi "portofolio" di pihak lain (jual beli surat berharga yang diterbitkan lembaga luar negeri untuk mendapat keuntungan tanpa ikut serta mengendalikan atau mengelola) baru pada tahun 1960-an muncul, bersamaan dengan munculnya isttilah Multi National Corporation atau MNC (Hirst, et.al, 2001). Berdasarkan paparan tersebut mengenai globalisasi sebenarnya sudah ada sejak abad ke-14, namun istilah ini baru familiar pada akhir-akhir ini. Terlepas kontroversi pendapat para pakar ekonomi tentang kapan sebenarnya era globalisasi di mulai, paling tidak benih-benih globalisasi sebenarnya sudah muncul beberapa abad yang lalu.

\section{TEORI DAN METODE}

\subsection{Kajian Teori}

Dunia saat ini memasuki abad ke-21, satu abad yang diwarnai oleh fenomena globalisasi dan revolusi informatika yang menyentuh pada semua bidang kehidupan. Abad ini ditandai dengan terjadinya perubahan yang serba cepat dan kompleks baik yang menyangkut pada perubahan nilai maupun struktur kehidupan. Sebagaimana yang telah dikemukakan oleh Achmad Sanusi bahwa :"Apa yang disaksikan dan dialami selama perjalanan, seminar, konsultasi, tukar pikiran, membaca surat kabar, menonton televisi, dan akses ke homepage internet dan sebagainya cukup meyakinkan diri bahwa segala Real Life System (RLS) dimana-mana telah nyata bergerak, berubah secara luas dan cepat serta semakin mengglobal. Proses itu menghadapkan individu, organisasi dan alam bukan saja ke dalam suatu keteraturan 
dan kerjasama, namun juga menciptakan kompetisi untuk saling mengungguli, kompleksitas dan kesemrawutan.

Perubahan yang cepat dan mengglobal ini bisa terjadi karena didukung perkembangan ilmu pengetahuan dan teknologi yang semakin pesat. Negara dan bangsa yang dibekali dengan ilmu pengetahuan dan teknologi yang maju akan dapat menguasai dunia.

Kenyataan bahwa dunia sekarang dirasakan semakin sempit. Jarak Fisik negara tidak lagi menjadi hambatan dalam melakukan interaksi dan komunikasi. Hubungan antar negara bukan hanya mengandalkan hubungan langsung, tetapi bisa melalui teleconference serta berbagai wahana telekomunikasi lainnya yang semakin hari semakin cangggih.

Dalam keadaan demikian, umat manusia ditantang untuk mengantisipasi perubahan yang terjadi dalam kehidupan di masa sekarang dan masa mendatang. Batas-batas yang meliputi wilayah, politik, ekonomi, budaya, bahkan jatidiri, kepribadian serta nilai sedang mengalami tantangan. Untuk menjawab tantangan itu, kuncinya adalah dengan melakukan upaya peningkatan kualitas sumber daya manusia (SDM). Era informasi dan globalisasi yang sedang berlangsung ini harus dihadapi dengan rasa percaya diri, kualitas SDM yang handal, tajam dan cermat dalam memanfaatkan momentum positif serta mengantisipasi segi negatifnya secara rasional.

Pembangunan dan pembinaan yang tangguh pada masyarakat bukan hanya terarah kepada aspek intelektual, keterampilan dan etos kerjanya semata, melainkan yang lebih utama adalah kepada aspek moral dan mentalnya, sehingga dapat memunculkan apa yang kemudian disebut manusia seutuhnya, yaitu manusia yang memiliki keseimbangan aspek moral (mental) dengan aspek kecerdasan, keterampilan dan etos kerja (Rudy, 2007).

Salah satu konsekuensi adanya globalisasi adalah perusahaan dapat berekspansi dari satu negara ke negara lain. Perusahaan yang mampu berkompetisi dan mempunyai keunggulan bersaing akan menjadi pemenang. Maka tidaklah mengherankan, banyak perusahaan Multi National Corporation (MNC) maupun Transnasional Corporation (TNC) yang beroperasi di luar negara darimana perusahaan tersebut berada. Sering terjadi bahwa istilah MNC dan TNC dicampuraduk atau dianggap sama. Sesungguhnya keduanya ada perbedaan jika dilihat dari segi kepemilikan modal, di samping juga adanya persamaan dalam pelaksanaan kegiatan usahanya dan produksi di luar negara atau operasionalisasi produksi dan penjualan secara lintas batas negara.

Tepatnya yang digolongkan perusahaan sebagai MNC adalah perusahaan yang dimiliki bersama-sama oleh pemilik modal atau pemegang saham utama yang berasal dari lebih satu bangsa. Sehingga kewenangan mengatur modal dan kegiatan operasional perusahaan tidak berada dalam tangan kapitalis satu bangsa tertentu.

Sedikit berbeda dengan perusahaan TNC yang kepemilikan modal perusahaan berada di tangan seorang atau beberapa orang pemodal dari satu kebangsaan. Contohnya perusahaan-perusahaan TNC Jepang di bidang otomotif (Toyota, Honda, Mitsubishi, Daihatsu, Suzuki), atau perusahaan software computer dari Amerika Serikat (IBM sepenuhnya dikendalikan Bill Gates). TNC memiliki kesamaan dengan MNC dalam internasionalisasi modal dan investasi, tetapi berbeda dalam hal penguasaan kepemilikan modal (Rudy, 2007).

Suatu negara ataupun perusahaan melakukan transaksi bisnis internasional baik dalam bentuk perdagangan internasional maupun dalam bentuk bisnis 
internasional pada umumnya memiliki beberapa pertimbangan atau alasan. Pertimbangan tersebut meliputi pertimbangan ekonomis, politis ataupun sosial budaya bahkan tidak jarang atas dasar pertimbangan militer. Bisnis internasional memang tidak dapat dihindarkan karena sebenarnya tidak ada satu negara pun di dunia ini yang dapat mencukupi seluruh kebutuhan negerinya atau masyarakatnya dari barang-barang-barang atau produk yang dihasilkan oleh negara itu sendiri. Tidak ada satu negara pun yang dapat memenuhi $100 \%$ swasembada (self sufficiency). Ataupun kala ada yang mampu melakukan swasembada justru secara ekonomis tidak efisien. Hal ini disebabkan karena terjadinya penyebaran yang tidak merata dari sumber daya baik sumber daya alam maupun sumber daya manusia.

Adapun beberapa alasan untuk melaksanakan bisnis internasional antara lain berupa:

1. Spesialisasi antara Bangsa-Bangsa

Alasan ini merupakan alasan yang mendasarkan diri pada kenyataan bahwa setiap negara memiliki suatu keunggulan tertentu ketimbang negara lain. Disamping memiliki keunggulan setiap negara juga akan memiliki kelemahan tertentu dibandingkan dengan negara lain. Dalam hubungannya dengan keunggulan atau kekuatan tertentu beserta kelemahannya itu maka suatu negara haruslah menentukan pilihan strategis untuk memproduksikan suatu komoditi strategis yaitu:

a. Memanfaatkan semaksimal mungkin kekuatan yang ternyata benar-benar paling unggul sehingga dapat menghasilkannya secara lebih efisien dan paling murah diantara negara-negara lain.

b. Menitikberatkan pada komoditi yang memiliki kelemahan paling kecil di antara negara-negara lain.

c. Mengkonsentrasikan perhatiannya untuk memproduksikan atau menguasai komoditi atau perdagangan komoditi atau perdagangan komoditi yang memiliki kelemahan yang tertinggi bagi negerinya.

2. Pertimbangan Pengembangan Bisnis

Perusahaan yang sudah bergerak di bidang tertentu dalam suatu bisnis di dalam negeri seringkali lalu mencoba untuk mengembangkan pasarnya ke luar negeri. Kekuatan-kekuatan bisnis yang telah dimilikinya untuk melayani pasar di dalam negeri dapat dikembangkannya untuk melayani pasar luar negeri secara lebih kompetitif. Hal ini akan menimbulkan beberapa pertimbangan yang mendorong mengapa suatu perusahaan melaksanakan atau terjun ke bisnis internasional yaitu:

a. Memanfaatkan kapasitas mesin yang masih menganggur yang dimiliki oleh suatu perusahaan.

b. Produk tersebut di dalam negeri sudah mengalami tingkat kejenuhan bahkan mungkin sudah mengalami tahap penurunan (decline phase), sedangkan di luar negeri justru sedang berkembang (growth).

c. Persaingan yang terjadi di dalam negeri kadang justru lebih tajam ketimbang persaingan terhadap produk tersebut di luar negeri.

d. Mengembangkan pasar baru (ke luar negeri) merupakan tindakan yang jauh lebih mudah ketimbang mengembangkan produk baru (di dalam negeri).

e. Potensi pasar internasional pada umumnya jauh lebih luas ketimbang pasar domestik (Gitosudarmo, 2001).

Demikian pula ekspansi yang sedang dilakukan oleh perusahaan TNC dan MNC. Perusahaan ini dalam mengembangkan pasarnya tidak hanya meliputi bidang industri barang saja, tetapi juga bidang industri jasa, seperti bank. Beroperasinya 
bank-bank di beberapa negara dengan cara membeli saham bank setempat (di suatu negara tertentu) merupakan jenis MNC, tidak terkecuali di Indonesia. Bank Danamon, Standard Carter dan masih banyak lagi adalah contoh industri jasa MNC. Inilah yang dinamakan bisnis atau perdagangan internasional.

Dalam memasuki pasar skala global tentunya perusahaan harus memiliki strategi yang tepat untuk memenangkan persaingan. Strategi bersaing global adalah strategi untuk memperoleh keunggulan posisi dalam arena persaingan yang dipilih dalam lingkup umum atau dalam hal ini adalah internasional. Langkah pertama dalam menyusun keunggulan bersaing adalah menentukan dulu batas-batas arena persaingan. Tanpa mempertajam pasar yang dituju dan pesaing-pesaing yang dihadapi, strategi bersaing sulit untuk dibangun dengan efektif. Pesaing dapat berupa pesaing yang berhadap frontal dalam persaingan bentuk produk yang sama atau pesaing ditingkat-tingkat yang lebih luas (Budiharjo, 2011).

Adapun strategi yang dapat dilakukan suatu perusahaan untuk memenangkan persaingan melalui tiga jenis strategi : korporasi, bisnis dan fungsional.

a. Strategi Korporasi

Strategi ini menspesifikasi apa yang akan dimasuki atau yang ingin dimasuki dan apa yang ingin dikerjakan oleh perusahaan dengan bisnis tersebut. Ini didasarkan pada misi dan tujuan organisasi serta peranan yang akan dimainkan setiap unit bisnis organisasi. Bagian lain dari strategi korporasi adalah manajer puncak memutuskan apa yang akan dilakukan dengan bisnis-bisnis tersebut. Jenis strategi ini melalui strategi pertumbuhan, strategi stabilitas dan strategi pembaharuan.

b. Strategi Kompetitif

Strategi ini tentang bagaimana organisasi akan bersaing dalam bisnisnya. Bagi organisasi yang hanya berkecimpung dalam satu lini bisnis atau organisasi besar yang belum terdiversifikasi dalam berbagai produk atau pasar, strategi kompetitif menggambarkan bagaimana organisasi tersebut akan bersaing di pasar primer atau utamanya.

c. Strategi Fungsional

Strategi fungsional yaitu strategi yang digunakan oleh berbagai departemen fungsional organisasi untuk mendukung strategi kompetitif (Robbins, et.al, 2010).

Kalau kita lihat dewasa ini ada fenomena menarik yang perlu mendapat kajian di industri jasa perbankan dalam skala global, khususnya di negara Inggris. Praktik bank konvensional skala internasional saat ini mulai mendapat pesaing baru yaitu mulai masuknya bank syariah yang menerapkan konsep syariah Islam di negara Inggris. Seperti kita ketahui bahwa masyarakat Inggris sebagian besar adalah NonMuslim. Di luar prediksi para pakar ekonomi, ternyata bank syariah tidak hanya mendapat sambutan positif di negara-negara Islam yang mayoritas penduduknya Islam, namun juga di negara yang jumlah penduduk Islamnya minoritas, seperti di Inggris yang merepresentasikan negara Eropa.

Berdasarkan fenomena tersebut maka dalam penelitian ini bertujuan untuk mengetahui,

(1). Analisis Strategi Bank Syariah untuk memasuki pasar di negara Inggris.

(2). Prospek Bank Syariah di masa yang akan datang di negara Inggris.

\subsection{Metodologi Penelitian}

Metode penelitian menggunakan kualitatif yaitu metode penelitian yang berlandaskan pada filsafat postpositivisme yaitu memandang realitas sosial sebagai suatu yang holistik/utuh, kompleks, dinamis, penuh makna, dan hubungan gejala 
bersifat interaktif (Narbuko, et.al, 2002). Metode kualitatif bersifat diskriptif, yakni data yang terkumpul berbentuk kata atau gambar, tidak hanya menekankan pada angka (Sugiono, 2008). Adapun pendekatan yang digunakan adalah fenomenalogi yaitu metodelogi kualitatif yang mengizinkan peneliti menerapkan dan mengaplikasikan kemampuan subyektif dan interpersonalnya dalam proses eksploratori (Alase, 2017). Adapun sumber data diperoleh dari data sekunder yaitu sumber data yang tidak langsung memberikan data kepada pengumpul data, misalkan dokumen, jurnal, hasil penelitian, buku, dan peraturan pemerintah (Basrowi, 2008).

\section{PEMBAHASAN}

\subsection{Perkembangan Penduduk Muslim di Dunia}

Penduduk Muslim pada dekade ini mengalami pertumbuhan yang sangat pesat. Menurut data yang di-release Ensiklopedi Wikipedia pada tahun 2010, lebih dari 1,6 miliar atau 23,4\% dari populasi dunia adalah Muslim. Dari jumlah tersebut, sekitar 62\% di Asia-Pasifik, 20\% di Tengah Afrika Timur-Utara, 15\% di Afrika Sub-Sahara, sekitar 3\% di Eropa dan 0,3\% di Amerika.

Sementara publikasi lain dari World Muslim Population memberikan data bahwa populasi Muslim meningkat 1,84\%. Populasi Muslim pada tahun 2012 adalah 2.013,62 juta atau 2,1 miliar. Menurut proyeksi para peneliti dari Pew Research Center's Forum on Religion \& Public Life, Cooperman tahun 2011 dalam laporan yang dipublikasikan mengemukakan, populasi penduduk Muslim dunia 20 tahun ke depan diperkirakan akan meningkat sekitar 35\%. Hal ini mengalami kenaikan mulai dari 1,6 miliar jiwa tahun 2010 hingga mencapai 2,2 miliar pada tahun 2030.

Secara global, penduduk Muslim diperkirakan tumbuh sekitar dua kali lipat dibanding dengan populasi non-Muslim selama dua dekade berikutnya. Tingkat pertumbuhan tahunan rata-rata 1,5\% untuk umat Islam dan 0,7\% untuk penduduk non-Muslim. Jika kecenderungan ini terus berlanjut, umat Islam akan membentuk $26,4 \%$ dari total penduduk dunia yaitu diproyeksikan sebesar 8,3 miliar pada tahun 2030, naik 23,4\% (estimasi tahun 2010 penduduk dunia sebesar 6,9 miliar).

Populasi penduduk Muslim global diperkirakan akan tumbuh pada tingkat yang lebih cepat daripada non-Muslim. Berdasarkan paparan data dari The Pew Forum on Religion \& Public Life (2012) dalam laporan analisis distribusi penduduk Muslim dunia dapat dikemukakan, penduduk Muslim terkonsentrasi di kawasan Asia-Pasifik sejumlah 62\% (enam dari sepuluh negara Muslim dunia). Penduduk Muslim juga banyak yang tinggal di Timur Tengah dan Afrika Utara (20\%) dan sub-Sahara Afrika (16\%). Sisa dari populasi Muslim dunia adalah Eropa (3\%). Amerika Utara (kurang dari 1\%) dan Amerika Latin dan Karibia (juga kurang dari 1\%) sebagai mana tabel 1 di bawah ini,

Tabel 1. Distribusi Populasi Muslim Dunia Berdasarkan Benua (Region)

\begin{tabular}{|r|r|r|c|}
\hline & $\begin{array}{c}\text { Muslim } \\
\text { Population } \\
\text { (estimasi 2010) }\end{array}$ & $\begin{array}{c}\text { Total Population } \\
\text { (estimasi 2010) }\end{array}$ & $\begin{array}{c}\text { Percentage of } \\
\text { Population That } \\
\text { is Muslim (\%) }\end{array}$ \\
\hline $\begin{array}{r}\text { Asia-Pasifik } \\
\text { Timur Tengah-Afrika }\end{array}$ & 385.530 .000 & 4.054 .990 .000 & 24,3 \\
Utara & 317.070 .000 & 341.020 .000 & 93,0 \\
Sub-Sahara Afrika & 248.110 .000 & 822.720 .000 & 30,2 \\
Eropa & 43.490 .000 & 742.550 .000 & 5,9 \\
\hline
\end{tabular}




\begin{tabular}{|r|r|r|c|}
\hline Amerika Latin-Karibia & 3.480 .000 & 344.530 .000 & 1,0 \\
& 840.000 & 590.080 .000 & 0,1 \\
\hline Total & 1.598 .520 .000 & 6.895 .890 .000 & 23,2 \\
\hline
\end{tabular}

Sumber: Pew Research Center's Forum on Religion \& Public Life-The Globa Religious Landscape (Desember, 2012)

Sementara jumlah penduduk Muslim dunia yang jumlahnya mencapai 1,5 miliar jiwa terdistribusi pada beberapa negara (lihat tabel 2). Berikut data sepuluh negara dengan jumlah Muslim terbesar (66\% dari total Muslim dunia). Indonesia merupakan negara dengan populasi terbanyak sebesar 13\%, diikuti oleh India (11\%), Pakistan (11\%), Bangladesh (8\%), Nigeria (5\%), Mesir (5\%), Iran (5\%), Turki (5\%), Aljazair (2\%) dan Maroko (2\%).

Tabel 2. Sepuluh Negara dengan Jumlah Penduduk Muslim Terbesar

\begin{tabular}{|r|r|r|c|}
\hline & $\begin{array}{l}\text { Populasi Muslim } \\
\text { (Estimasi 2010) }\end{array}$ & $\begin{array}{l}\text { Persentase Populasi } \\
\text { Penduduk Muslim } \\
(\%)\end{array}$ & $\begin{array}{l}\text { Persentase } \\
\text { Populasi Muslim } \\
\text { Dunia (\%) }\end{array}$ \\
\hline $\begin{array}{r}\text { Indonesia } \\
\text { India }\end{array}$ & 209.120 .000 & 87,2 & 13,1 \\
Bangladan & 176.190 .000 & 14,4 & 11,0 \\
Nigeria & 167.410 .000 & 96,4 & 10,5 \\
Mesir & 733.540 .000 & 89,8 & 8,4 \\
Iran & 77.300 .000 & 48,8 & 4,8 \\
Turki & 73.990 .000 & 94,9 & 4,6 \\
Algeria & 31.330 .000 & 99,5 & 4,5 \\
Maroko & 31.730 .000 & 98,0 & 2,2 \\
\hline Subtotal (10 Negara & 1.052 .120 .000 & 97,9 & 65,8 \\
Subtotal For Rest of & & 99,99 & 34,2 \\
World & 546.400 .000 & 11,7 & 100,0 \\
Total & 1.598 .510 .000 & 23,2 & \\
\hline
\end{tabular}

Sumber: Pew Research Center's Forum on Religion \& Public Life-The Global Religious Landscape (Desember, 2012)

Sementara populasi Muslim global diperkirakan akan tumbuh pada tingkat yang lebih cepat daripada populasi non-Muslim, populasi Muslim tetap diperkirakan akan tumbuh pada kecepatan yang lebih lambat dalam dua decade mendatang dibandingkan pada dua dekade sebelumnya. Dari tahun 1990 hingga 2010, populasi Muslim global meningkat pada tingkat tahunan rata-rata 2,2\%, dibandingkan dengan tingkat proyeksi 1,5\% untuk periode 2010-2030. Secara lebih detail dapat dilihat pada tabel 3 berikut ini

Tabel 3. Pertumbuhan Penduduk Muslim Bagian dari Populasi Dunia (1990-2030)

\begin{tabular}{|c|c|c|c|c|c|}
\hline Tahun & $\begin{array}{c}\text { Muslim } \\
\text { (Milyar) }\end{array}$ & $\mathbf{\%}$ & $\begin{array}{c}\text { Non-Muslim } \\
\text { (Milyar) }\end{array}$ & $\mathbf{\%}$ & $\begin{array}{c}\text { Total } \\
\text { (Milyar) }\end{array}$ \\
\hline 1990 & 1,1 & 19,9 & 4,2 & 80,1 & 5,3 \\
2000 & 1,3 & 21,6 & 4,8 & 78,4 & 6,1 \\
2010 & 1,6 & 23,4 & 5,3 & 76,6 & 6,9 \\
2020 & 1,9 & 24,9 & 5,8 & 75,1 & 7,7 \\
2030 & 2,2 & 26,4 & 6,1 & 73,6 & 8,3 \\
\hline
\end{tabular}

Sumber : Pew Research Center's Forum on Religion \& Public Life-The Future of the Global Muslim Population (Januari, 2011) 
Laporan oleh Pew Forum on Religion \& Public Life berusaha memberikan data yang up-to-date perkiraan jumlah muslim di seluruh dunia pada tahun 2010 dan memproyeksikan pertumbuhan penduduk Muslim 2010-2030. Proyeksi ini didasarkan baik pada tren demografi masa lalu dan pada asumsi tentang proyeksi ini didasarkan baik pada tren ini akan dipergunakan pada tahun-tahun mendatang. Membuat proyeksi ini pasti akan menemui kondisi sejumlah ketidakpastian, termasuk aspek politik. Misalnya perubahan iklim politik di Amerika Serikat atau negara-negara Eropa secara drastis juga dapat mempengaruhi pola migrasi penduduk Muslim. Berikut ini tabel 4 estimasi angka pertumbuhan penduduk Muslim hingga tahun 2030.

Tabel 4. Estimasi dari Proyeksi Penduduk Muslim Global Tahun 2010 dan 2030.

\begin{tabular}{|r|l|l|l|l|}
\hline & Tahun 2010 & & Tahun 2030 & \\
\hline & $\begin{array}{l}\text { Estimasi } \\
\text { Populasi } \\
\text { Penduduk } \\
\text { Muslim }\end{array}$ & $\begin{array}{l}\text { Estimasi } \\
\text { Persentase } \\
\text { Populasi } \\
\text { Penduduk } \\
\text { Muslim } \\
\text { Global }(\%)\end{array}$ & $\begin{array}{l}\text { Proyeksi } \\
\text { Populasi } \\
\text { Penduduk } \\
\text { Muslim }\end{array}$ & $\begin{array}{l}\text { Proyeksi } \\
\text { Persentase } \\
\text { Populasi } \\
\text { Penduduk } \\
\text { Muslim } \\
\text { Global (\%) }\end{array}$ \\
\hline Dunia & 1.619 .314 .000 & 100,0 & 2.190 .154 .000 & 100,0 \\
Asia-Pasifik & 1.005 .507 .000 & 62,1 & 1.295 .625 .000 & 59,2 \\
Timur Tengah- & 321.869 .000 & 19,9 & 439.453 .000 & 20,1 \\
Afrika Utara & & 15,0 & 385.939 .000 & 17,6 \\
Sub Sahara Afrika & 242.544 .000 & & 58.209 .000 & 2,7 \\
Eropa & 44.138 .000 & 2,7 & 10.927 .000 & 0,5 \\
\hline
\end{tabular}

Sumber : Pew Research Center's Forum on Religion \& Public Life-The Future of The Global Muslim Population (Januari, 2011)

Beberapa faktor yang berkontribusi mempengaruhi kecepatan pertumbuhan penduduk Muslim disbanding penduduk non-Muslim di seluruh dunia. Umumnya, populasi penduduk Muslim cenderung memiliki tingkat kesuburan yang lebih tinggi (lebih banyak menghasilkan anak perempuan) daripada populasi non-Muslim. Selain itu, pada umumnya populasi Muslim banyak yang segera memasuki tahun-tahun reproduksi awal yaitu pada usia 15-29 tahun. Meningkatnya kesehatan dan kondisi ekonomi di negara-negara mayoritas Muslim juga menyebabkan menurunnya tingkat kematian bayi dan anak. Keadaan ekonomi dan kesehatan yang baik pula dapat menciptakan harapan hidup di negara-negara yang memiliki mayoritas penduduk Muslim. Di samping itu, kualitas pendidikan yang meningkat dan keuletan umat Muslim dalam melakukan migrasi demi membuka harapan baru dalam berbisnis juga turut serta menentukan pertumbuhan penduduk Muslim secara signifikan (Asnawi, 2017).

Selain itu ada beberapa faktor lain yang mendorong pertumbuhan Muslim di Eropa, yaitu : pertumbuhan populasi melalui migrasi dan pengungsi. Kondisi ini di dorong oleh konflik di Afrika dan Timur Tengah yang mayoritas masyarakatnya Muslim. Berapa besar arus migrasi juga sangat tergantung pada kebijakan politik setiap negara, yang bisa berubah-ubah. Jika migrasi dihentikan saat ini juga, populasi Muslim di Eropa tetap akan tumbuhan lebih cepat darpada populasi secara keseluruhan. Hal ini terjadi karena adanya perbedaan struktur usia dan fertilitas 
antara warga Muslim dan non-Muslim Eropa sebagaimana diuraikan pada hipotesa di atas.

Antara tahun 2010 sampai 2016, ada 7 juta orang dari semua latar belakang agama tiba di Eropa sebagai migran regular atau pengungsi. Lebih dari setengah $(3,7$ juta) adalah Muslim. Hanya 1,6 juta dari total 7 juta orang yang punya status pengungsi. Sebagian besar pengungsi adalah Muslim (1,3 juta). Ini mencerminkan kondisi di Suriah, Irak dan Afghanistan yang dilanda perang dan konflik berkepanjangan, sedangkan lainnya datang ke Eropa sebagai migran regular.

Faktor tambahan yang mungkin mempengaruhi jumlah populasi Muslim di masa depan adalah penyatuan kembali keluarga. Pencari suaka yang diterima umumnya diizinkan untuk memboyong keluarga dekat.

Sedangkan pertumbuhan penduduk Muslim di Inggris dari tahun ke tahun sangat signifikan, hal ini dapat dilihat pada tabel 5 berikut ini:

Tabel 5. Pertumbuhan Penduduk Muslim di Inggris

\begin{tabular}{|l|l|l|l|l|l|}
\hline $\begin{array}{l}\text { Sensus } \\
\text { Tahunan }\end{array}$ & Jumlah Muslim & $\begin{array}{l}\text { Populasi } \\
\text { Inggris dan } \\
\text { Wales }\end{array}$ & $\begin{array}{l}\text { Muslim } \% \\
\text { dari total } \\
\text { populasi) }\end{array}$ & $\begin{array}{l}\text { Masjid } \\
\text { yang } \\
\text { terdaftar }\end{array}$ & $\begin{array}{l}\text { Muslim } \\
\text { per- } \\
\text { Masjid }\end{array}$ \\
\hline 1961 & 50.000 & $46,196.000$ & 0.11 & 7 & 7,143 \\
1971 & 226.000 & $49,152.000$ & 0.46 & 30 & 7,533 \\
1981 & 553.000 & 49.634 .000 & 1.11 & 149 & 3,711 \\
1991 & 950.000 & 51.099 .000 & 1.86 & 443 & 2,144 \\
2001 & 1.600 .000 & 52.042 .000 & 3.07 & 614 & 2,606 \\
2011 & 2.869 .000 & 62.369 .000 & 4.80 & 1,500 & 1,912 \\
\hline
\end{tabular}

Sumber : Jurnal Rihlah Vol. II No. 1 Mei 2015, Islam di Inggris (Tinjauan Historis Dinamika Kehidupan Muslim), UIN Alauddin Makasar.

Dapat dilihat bahwa pertumbuhan Muslim di Inggris dari tahun ke tahun meningkat. Pada Tahun 1961 jumlah penduduk muslim Inggris hanya sekitar 50.000 orang dari 46.196.000 total penduduk Inggris. Pada tahun tersebut jumlah masjid hanya 7 buah itu artinya sekitar 7.143 muslim tiap masjid. Pada tahun 2001, jumlah Muslim sekitar 1.600 .000 dari 52.042.000, hal ini berarti peningkatan signifikan sekitar 6 juta penduduk dari tahun 1961-2001, hampir 0,25\% dipengaruhi oleh peningkatan jumlah penduduk Muslim di Inggris. Terlebih lagi, pada tahun 2011, jumlah penduduk Muslim meningkat menjadi 2.869.000 orang dari total penduduk 63.369.000 orang atau sekitar 4,80\% (Mundzir, 2015). Bagi bisnis syariah ini merupakan pasar yang bagus mengingat populasi penduduk muslim terus meningkat di Inggris.

\subsection{Pertumbuhan Penduduk Muslim di Inggris dan Konsekuensi Ekonomi}

Dalam beberapa dekade terakhir ini masyarakat Muslim mengalami aktivitas yang sangat pesat khususnya di bidang bisnis dengan berkecimpung di berbagai sektor produktif, antara lain sebagai pelaku aktif di bidang investasi (investor) dan penguasaan perusahaan manufaktur, banker dan trader, pemasok serta menjadi partner bisnis dalam sistem perekonomian global.

Penduduk Muslim sekaligus berprofesi sebagai pengusaha juga mengalami pertumbuhan yang sangat pesat. Konsekuensi dari pertumbuhan ini maka ke depannya akan menciptakan peluang bagi munculnya potensi-potensi bisnis baru. Kemudian muncul pertanyaan siapa sebenarnya konsumen Muslim itu? Menurut ensiklopedi Wikipedia (2013) istilah konsumen Muslim tidak lepas dari komunitas dunia Muslim. Istilah dunia Islam (juga dikenal sebagai umat Muslim) memiliki beberapa arti. Dalam arti religius, mengacu pada orang-orang yang mengikuti ajaran 
Islam, disebut sebagai Muslim. Sedangkan dalam perspektif budaya, mengacu pada peradaban Islam, termasuk orang non-Muslim yang tinggal di lingkungan atau negara Islam. Islam menekankan kesatuan gaya hidup dan keeratan hubungan sesama Muslim (silaturahim), meskipun banyak juga aliran-aliran yang diyakini oleh pemeluk agama Islam itu sendiri, misalnya Syiah, Sunni, dan Ahlussunnah wal jamaah (Asnawi, et.al, 2017).

Konsumen Muslim adalah homogen, mereka memiliki komunitas kehidupan yang heterogen, berbicara menggunakan bahasa yang berbeda-beda, berbusana secara berbeda, memiliki pendidikan yang berbeda, dan berpola konsumsi yang berbeda-beda pula. Tradisi dunia Muslim sendiri mengalami perubahan drastis. Di beberapa negara Islam banyak wanita yang tetap benar-benar tertutup oleh burqa. Di taliban Afghanistan perempuan tidak diperbolehkan untuk memperoleh pendidikan formal, sedangkan di Kuwait, Qatar dan Oman wanita diperbolehkan untuk memilih. Sedangkan di Pakistan, Suriah, Bahrain dan Uni Emirat Arab (UEA), bahkan wanita mampu mengisi pos-pos penting di pemerintahan seperti menteri dan politisi. Termasuk di Indonesia, peta perubahan politik juga turut serta memberikan harapan baru bagi kehadiran wanita untuk berkiprah di dunia politik dan pemerintahan. Karena globalisasi memaksa negara-negara Muslim untuk terus adaptif terhadap perubahan zaman maka banyak pula penduduk Muslim baik yang laki-laki maupun perempuan memiliki kemandirian ekonomi dengan dibuktikannya pendapatan per kapita penduduk Muslim di berbagai negara (Walker, et.al, 2007).

Sementara itu perekonomian Uni Eropa (UE) tahun lalu 2017 tercatat tumbuh pada laju tercepat dalam satu dekade, berdasarkan dari kantor statistik UE Eurostat yang telah mengkonfirmasi. UE yang beranggotakan 28 negara mengalami peningkatan 2,5\% di tahun 2017 untuk menjadi kinerja terkuat sejak 2007 atau tumbuh 2,7\%. Dalam tiga bulan terakhir 20017, baik itu UE dan Zona Euro dengan 19 negara tumbuh mencapai $0,6 \%$ dibandingkan kuartal sebelumnya. Hal ini tercermin dari pertumbuhan ekonomi terbesar Uni Eropa yakni Jerman yang meningkat mencapai sebesar 0,6\% pada kuartal terakhir 2017.

Ekonomi Perancis juga tercatat meningkat sebesar 0,6\% sedangkan pertumbuhan Spanyol berada pada level yang lebih kuat di level 0,7\%. Secara keseluruhan pada 2017, zona euro tumbuh sebesar 2,5\% dimana Eurostat menjelaskan tingkat pertumbuhan ini tercepat sejak kenaikan 3\% di tahun 2007.

Sebagian besar pertumbuhan tahun lalu didorong oleh empat negara inti zona euro seperti Jerman, Prancis, Italia dan Spanyol. Namun, ekonomi Eropa Timur, termasuk Latvia dan Slovakia, juga tumbuh sangat cepat. Lebih lanjut dia menghubungkan kekuatan zona euro dengan kebijakan stimulus Bank Sentral Eropa (ECB), yang telah menurunkan biaya pinjaman dalam beberapa tahun terakhir. Sementara itu, Inggris yang telah meninggalkan Uni Eropa (UE), pertumbuhan Produk Domestik Bruto (PDB) kuartalan sebesar 1.4\% sehingga tahun 2017 pertumbuhannya hanya 1,7\% atau 39,804.983 USD (Data diolah oleh CEICDATA, 2018).

Meskipun pertumbuhan tingkat ekonomi yang tidak fantantis namun tetap positif di beberapa negara Eropa (khususnya Inggris) merupakan peluang dan kesempatan bagi para investor untuk menanamkan modal untuk investasi, begitu pula perusahaan untuk berekspansi atau memperluas pasarnya. Iklim usaha yang kondusif dan daya beli konsumen yang baik akan mendorong perusahaan tumbuh dan berkembang, tidak hanya perusahaan lokal-nasional juga bagi perusahaan multinational dan transnasional. Tuntutan mengglobal bisa menjadi beban berat bagi 
perusahaan, namun perusahaan yang memasuki bisnis global memperoleh manfaat meningkatkan penjualan dan laba.

\subsection{Bank Syariah dan Strategi Memasuki Pasar Eropa}

Bunga secara fikih dikategorikan sebagai riba (dan karenanya haram), maka mulai timbul usaha-usaha di sejumlah negara muslim untuk mendirikan lembaga alternatif terhadap bank yang ribawi ini. Hal ini terjadi terutama setelah bangsabangsa muslim mendapatkan kemerdekaannya dari penjajahan bangsa-bangsa Eropa. Usaha modern pertama untuk mendirikan bank tanpa bunga pertama kali dilakukan di Malaysia pada pertengahan tahun 40-an, namun usaha ini tidak sukses (Haron, 1994).

Selanjutnya, eksperimen lainnya dilakukan di Pakistan pada akhir tahun 50an, di mana suatu lembaga perkreditan tanpa bunga didirikan di pedesaan negara itu. Namun demikian, eksperimen pendirian bank syariah yang paling sukses dan inovatif di masa modern ini dilakukan di Mesir pada tahun 1963, dengan berdirinya Mit Ghamr Local Saving Bank. Bank ini mendapat sambutan yang cukup hangat di Mesir, terutama dari kalangan petani dan masyarakat pedesaan. Jumlah deposan bank ini meningkat luar biasa dari 17,560 di tahun pertama (1963/1964) menjadi 251,152 pada 1966/1967. Jumlah tabungan pun meningkat drastis dari LE40,944 di akhir tahun pertama (1963/1964) menjadi LE1,828,375 di akhir periode 1966/1967. Namun sayang, karena terjadi kekacauan politik di Mesir maka Mit Ghamr mulai mengalami kemunduran, sehingga operasionalnya diambil alih oleh National Bank of Egypt dan bank sentral Mesir pada 1967. Pengambilalihan ini menyebabkan prinsip nirbunga pada Mit Ghamr mulai ditinggalkan, sehingga bank ini kembali beroperasi berdasarkan bunga. Pada 1971 akhirnya konsep nir-bunga kembali dibangkitkan pada masa rezim Sadat melalui pendirian Nasser Social Bank. Tujuan bank ini adalah untuk menjalankan kembali bisnis yang berdasarkan konsep yang telah dipraktekkan oleh Mit Ghamr.

Kesuksesan Mit Ghamr ini memberi inspirasi bagi umat muslim di seluruh dunia, sehingga timbullah kesadaran bahwa prinsip-prinsip Islam ternyata masih dapat diaplikasikan dalam bisnis modern. Ketika Organisasi Konferensi Islam (OKI) akhirnya terbentuk, serangkaian konferensi internasional mulai dilangsungkan, di mana salah satu agenda ekonominya adalah pendirian bank Islam. Akhirnya terbentuklah Islamic Development Bank (IDB) pada bulan Oktober 1975 yang beranggotakan 22 negara Islam pendiri. Bank ini menyediakan bantuan finansial untuk pembangunan negara-negara anggotanya, membantu mereka untuk mendirikan bank Islam di negaranya masing-masing, dan memainkan peranan penting dalam penelitian ilmu ekonomi, perbankan dan keuangan Islam. Kini, bank yang berpusat di Jeddah-Arab Saudi itu telah memiliki lebih dari 43 negara anggota.

Pada perkembangan selanjutnya di era 70-an, usaha-usaha untuk mendirikan bank Islam mulai menyebar ke banyak negara. Beberapa negara seperti Pakistan, Iran dan Sudan, bahkan mengubah seluruh sistem keuangan di negara itu menjadi sistem nir-bunga, sehingga semua lembaga keuangan di negara tersebut beroperasi tanpa menggunakan bunga. Di negara Islam lainnya seperti Malaysia dan Indonesia, bank nir-bunga beroperasi berdampingan dengan bank-bank konvensional.

Kini, perbankan syariah telah mengalami perkembangan yang cukup pesat dan menyebar ke banyak negara, bahkan ke negara-negara Barat. The Islamic Bank International of Denmark tercatat sebagai bank syariah pertama yang beroperasi di Eropa, yakni pada tahun 1983 di Denmark. 
Kini, bank-bank besar dari negara-negara Barat seperti Citibank, ANZ Bank, Chase Manhattan Bank dan Jardine Fleming telah pula membuka Islamic window agar dapat memberikan jasa-jasa perbankan yang sesuai dengan syariat Islam. Lalu kegiatan tersebut diadopsi oleh masyarakat Eropa abad pertengahan, dan pengelolaannya dilakukan oleh institusi, namun kegiatannya mulai dilakukan dengan basis bunga. Karena mundurnya peradaban umat muslim dan penjajahan bangsa-bangsa Barat terhadap negara-negara muslim, maka evolusi praktek perbankan yang sesuai syariah sempat terhenti beberapa abad. Baru pada abad 20 ketika bangsa muslim mulai merdeka, terbentuklah bank syariah modern di sejumlah negara (Schultz, 1986).

Adapun perkembangan bank syariah dan lembaga keuangan Islam di Inggris dapat di lihat pada tabel 6 berikut ini:

Tabel 6. Perkembangan Lembaga Keuangan Islam di Inggris

\begin{tabular}{|c|c|c|}
\hline No & Tahun & Lembaga Keuangan Islam \\
\hline 1 & 1982 & - Al-Baraka International Bank \\
\hline 2 & 1996 & $\begin{array}{l}\text { - United Bank of Kuwait } \\
\text {-Al-Baraka International Bank }\end{array}$ \\
\hline 3 & 2003 & $\begin{array}{l}\text {-HSBC Amanah } \\
\text {-United Bank Of Kuwait } \\
\text {-Al-Baraka International Bank } \\
\text {-Rosette Merchant Bank }\end{array}$ \\
\hline 4 & 2004 & $\begin{array}{l}\text {-ABC International Bank } \\
\text {-Islamic Bank of Britain } \\
\text {-Bank Of Ireland } \\
\text {-HSBC Amanah } \\
\text {-United Bank of Kuwait } \\
\text {-Rosette Merchant Bank } \\
\text {-Al-Baraka International Bank }\end{array}$ \\
\hline 5 & 2005 & $\begin{array}{l}\text {-European Islamic Investment Bank (EIIB) } \\
\text {-ABC International Bank } \\
\text {-Islamic Bank of Britain } \\
\text {-Bank of Ireland } \\
\text {-HSBC Amanah } \\
\text {-United Bank of Kuwait } \\
\text {-Rosette Merchant Bank } \\
\text {-Al-Baraka International Bank } \\
\text {-Llyods Bank }\end{array}$ \\
\hline 6 & 2007 & $\begin{array}{l}\text {-Bank of London and The Middle East (BLME) } \\
\text {-European Islamic Investment Bank (EIIB) } \\
\text {-ABC International Bank } \\
\text {-Islamic Bank of Britain } \\
\text {-Bank of Ireland } \\
\text {-HSBC Amanah } \\
\text {-United Bank of Kuwait } \\
\text {-Rosette Merchant Bank } \\
\text {-Al-Baraka International Bank } \\
\text {-Llyods Bank }\end{array}$ \\
\hline 7 & 2008 & $\begin{array}{l}\text {-QIB.UK (European Finance House) } \\
\text {-Gethouse Bank }\end{array}$ \\
\hline
\end{tabular}




\begin{tabular}{|c|c|c|}
\hline & & $\begin{array}{l}\text {-British Islamic Insurance Co. } \\
\text {-Bank of The London and The Middle East (BLME) } \\
\text {-European Islamic Investment Bank (EIIB) } \\
\text {-ABC International Bank } \\
\text {-Islamic Bank of Britain } \\
\text {-Bank of Ireland } \\
\text {-HSBC Amanah } \\
\text {-United Bank of Kuwait } \\
\text {-Rosette Merchant Bank } \\
\text {-Llyods Bank } \\
\text {-Al-Baraka International Bank }\end{array}$ \\
\hline 8 & 2013 & $\begin{array}{l}\text {-Abu Dhabi Islamic Bank } \\
\text {-QIB.UK (European Finance House) } \\
\text {-Gethouse Bank } \\
\text {-British Islamic Insurance Co. } \\
\text {-Bank of The London and The Middle East (BLME) } \\
\text {-European Islamic Investment Bank (EIIB) } \\
\text {-ABC International Bank } \\
\text {-Islamic Bank of Britain } \\
\text {-Bank of Ireland } \\
\text {-HSBC Amanah } \\
\text {-United Bank of Kuwait } \\
\text {-Rosette Merchant Bank } \\
\text {-Llyods Bank } \\
\text {-Al-Baraka International Bank } \\
\text {-Cobalt Underwriting }\end{array}$ \\
\hline 9 & 2015 & $\begin{array}{l}\text {-Abu Dhabi Islamic Bank } \\
\text {-QIB.UK (European Finance House) } \\
\text {-Gethouse Bank } \\
\text {-British Islamic Insurance Co. } \\
\text {-Bank of The London and The Middle East (BLME) } \\
\text {-European Islamic Investment Bank (EIIB) } \\
\text {-ABC International Bank } \\
\text {-Islamic Bank of Britain } \\
\text {-Bank of Ireland } \\
\text {-HSBC Amanah } \\
\text {-United Bank of Kuwait } \\
\text {-Rosette Merchant Bank } \\
\text {-Llyods Bank } \\
\text {-Al-Baraka International Bank } \\
\text {-Cobalt Underwriting } \\
\text {-Asosiasi Asuransi Islam London didirikan }\end{array}$ \\
\hline
\end{tabular}

Sumber : UK Excellent in Islamic.Finance Gov.UK/ukti.diakses tanggal 23/11/2018

Dari beberapa kondisi yang ada di Inggris meliputi jumlah populasi penduduk Muslim yang berkembang dengan pesat, pertumbuhan ekonomi di Inggris yang mendukung dan perkembangan Bank Syariah dan Lembaga Keuangan Islam yang beberapa tahun terakhir ini mengalami perkembangan yang signifikan maka prospek usaha jasa berbasis syariah memiliki peluang yang cukup besar di masa mendatang di negara Inggris. Strategi korporasi para pemilik modal (Top Management) dalam 
memasuki pasar yang sedang mengalami pertumbuhan yaitu memperluas jumlah pasar yang dilayani atau produk yang ditawarkan, baik melalui bisnis yang sudah ada maupun melalui bisnis yang baru. Untuk Bank Syariah dan Lembaga Keuangan Islam yang ada di Inggris, lebih baik memilih bauran produk length product yaitu menawarkan varian produk syariah atau width product yaitu melalui diversifikasi bisnis jasa keuangan syariah.

Sementara strategi kompetitif yang harus dilakukan Middle Management sebagai pengejawantahan melalui strategi pengembangan unit bisnis strategik (strategic business units), misalnya usahanya tidak hanya di bank syariah tetapi juga asuransi syariah, pasar modal syariah, dan lain-lainnya. Strategi diferensiasi bisnis syariah yang berada di tengah masyarakat yang mayoritas beragama non-Muslim sudah tepat dengan membidik segmen atau relung yang sempit (ceruk pasar). Meski demikian, tidak menutup kemungkinan pengusaha non-Muslim juga akan memanfaatkan pembiayaan syariah, karena menganggap bahwa jenis pembiayaan ini lebih adil (sharing modal, bagi hasil, dan resiko) dibandingkan bank konvensional yang lebih condong ke kapitalis karena debitur (peminjam uang di bank) sebagai obyek dari kreditur (bank pemberi pinjaman).

Adapun strategi fungsional bagi Low Management adalah mengkoordinasikan antar fungsi-fungsi departemen (divisi) yang ada di perusahaan, sehingga masingmasing divisi saling mendukung dan dapat diberdayakan secara optimal sebagai keunggulan bersaing (competitive advantage).

\section{PENUTUP}

Globalisasi memberikan peluang perusahaan untuk mengembangkan pasarnya ke luar negeri. Tentunya perusahaan tersebut harus memiliki keunggulan kompetitif dibandingkan dengan para pesaingnya untuk memenangkan persaingan. Tolok ukur keunggulan kompetitif adalah kekuatan internal yang lebih baik dibandingkan pesaingnya, serta perusahaan tersebut mampu membenahi kelemahan yang ada di internal. Selain itu, faktor eksternal juga perlu mendapat perhatian, perusahaan harus jeli melihat kesempatan yang ada dan meminimalisir ancaman. Dengan demikian perusahaan mampu memformulasikan strategi yang tepat dan mengimplementasikannya. Tentunya evaluasi strategi harus dilakukan, mengingat perubahan kondisi internal dan eksternal senantiasa berubah, sehingga strategi yang tepat untuk menang di setiap persaingan yang semakin kompetitif dapat diraih.

Demikian pula perusahaan MNC maupun TNC yang memilih bidang usaha syariah. Selain faktor internal harus di diagnosis terus menerus dan memperbaiki kelemahannya, maka peluang faktor eksternal untuk mengembangkan bisnis syariahnya di Inggris merupakan kesempatan yang baik. Jumlah populasi Muslim yang meningkat dari tahun ke tahun dan kondisi pertumbuhan ekonomi yang positif memberikan peluang yang cukup bagus untuk memasuki bisnis syariah di Inggris. 


\section{Daftar Pustaka}

Alase, Abayomi, The Interpretative Phenomenological Analysis (IPA): A Guide to a Good Qualitative Research Approach, International Journal of Education and Literacy Studies, Vol. 5 No. 2, April 2017, DOI: 10.7575/aiac.ijels. v.5n.2p.9.

Asnawi, Nur \& Fanani, Muhammad Asnan; (2017) Pemasaran Syariah : Teori, Filosofi \& Isu-Isu Kontemporer, Rajawali Pers, Depok, Hlm. 55-58.

Basrowi, Suwandi. (2008). Memahami Penelitian Kualitatif, Rineka Cipta, Jakarta, Hlm 158.

Budiharjo, Andreas.(2011). Pijar-Pijar Manajemen Bisnis Indonesia, Prasetya Mulya Publishing, Jakarta, Hlm 112.

Gitosudarmo, Indriyo.(2001). Manajemen Strategis, BPFE, Yogayakarta, Hlm. 310-314. Haron, Sudin, Islamic Banking: Rules and Regulations, Pelanduk Publications, Petaling Jaya, 1997, h. 2. Lihat dalam Sami Hassan Homoud, Progress of Islamic Banking: The Aspirations and the Realities. Islamic Economic Studies, Vol. 2 No. 1, December 1994, Hlm. 71-80.

Hirst, Paul \& Thompson, Grahame, (2001), Globalisasi adalah Mitos, Yayasan Obor Indonesia, Jakarta, Hlm. 31-33.

Mundzir, Chaerul, Islam di Inggris (Tinjauan Historis Dinamika Kehidupan Muslim), Jurnal Rihlah Vol. II No. 1 Mei 2015 UIN Alauddin Makasar.

Narbuko, Cholid \& Ahmadi, Abu, (2002), Metodologi Penelitian, Bumi Aksara, Jakarta, HIm 1.

Rudy, Teuku May, (2007), Ekonomi Politik Internasional : Peran Domestik hingga Ancaman Globalisasi, Penerbit Nuansa Cendekia, Bandung, Hlm. 149-151

Robbins, Stephen P. \& Coulter, Mary; (2010), Manajemen, Edisi Kesepuluh, Jilid 1, Penerbit Erlangga, Jakarta, Hlm. 218-225.

Schultz, Mr. Erik Trolle,(1986), How the First Islamic Bank was Established in Europe, dalam Islamic Banking and Finance, Butterworths Editorial Staff, London, HIm. 43-52.

Sugiono; (2008) Metode Penelitian Pendidikan: Pendekatan Kuantitatif, Kualitatif dan $R \& D$, Bandung, Alfabeta, HIm 9.

Walker, Martin;(2007), Addressing the Muslim Market: Can you Afford Not to?, Coyright AT Kearney, Inc. All Right Reserved. Marketing and Communications 222 West Adams Street Chicago, Illinois 60606 USA, Hlm. 1-2. 